\title{
Novel cellobiose 2-epimerases for the production of epilactose from milk ultrafiltrate containing lactose
}

\author{
Manuel Krewinkel," Jana Kaiser, ${ }^{*}$ Michael Merz, ${ }^{*}$ Eva Rentschler, ${ }^{*}$ Beatrice Kuschel,, Jörg Hinrichs, $†$ \\ and Lutz Fischer ${ }^{* 1}$ \\ *Department of Biotechnology and Enzyme Science, and \\ †Department of Soft Matter Science and Dairy Technology, Institute of Food Science and Biotechnology, University of Hohenheim, \\ 70599 Stuttgart, Germany
}

\begin{abstract}
A selected number of enzymes have recently been assigned to the emerging class of cellobiose 2-epimerases (CE). All CE convert lactose to the rare sugar epilactose, which is regarded as a new prebiotic. Within this study, the gene products of 2 potential CE genes originating from the mesophilic bacteria Cellulosilyticum lentocellum and Dysgonomonas gadei were recombinantly produced in Escherichia coli and purified by chromatography. The enzymes have been identified as novel CE by sequence analysis and biochemical characterizations. The biochemical characterizations included the determination of the molecular weight, the substrate spectrum, and the kinetic parameters, as well as the $\mathrm{pH}$ and temperature profiles in buffer and food matrices. Both identified CE epimerize cellobiose and lactose into the $\mathrm{C} 2$ epimerization products glucosylmannose and epilactose, respectively. The epimerization activity for lactose was maximal at $\mathrm{pH} 8.0$ or 7.5 and $40^{\circ} \mathrm{C}$ in defined buffer systems for the $\mathrm{CE}$ from $C$. lentocellum and the CE from D. gadei, respectively. In addition, biotransformations of the foodstuff milk ultrafiltrate containing lactose were demonstrated. The CE from D. gadei was produced in a stirred-tank reactor (12 L) and purified using an automatic system. Enzyme production and purification in this scale indicates that a future upscaling of $\mathrm{CE}$ production is possible. The bioconversions of lactose in milk ultrafiltrate were carried out either in a batch process or in a continuously operated enzyme membrane reactor (EMR) process. Both processes ran at an industrially relevant low temperature of $8^{\circ} \mathrm{C}$ to reduce undesirable microbial growth. The enzyme was reasonably active at the low process temperature because the $\mathrm{CE}$ originated from a mesophilic organism. An epilactose yield of $29.9 \%$ was achieved in the batch process within $28 \mathrm{~h}$ of operation
\end{abstract}

Received February 2, 2015.

Accepted March 10, 2015.

${ }^{1}$ Corresponding author: Lutz.Fischer@uni-hohenheim.de time. In the continuous EMR process, the epilactose yield in the product stream was lower, at $18.5 \%$. However, the enzyme productivity was approximately 6 times higher because the continuous epilactose formation was carried out for about $6 \mathrm{~d}$ without further addition of biocatalyst. Within this time, $24 \mathrm{~g}$ of epilactose in $2.8 \mathrm{~L}$ of permeate were produced. The batch and the EMR process showed that the milk ultrafiltrate, which is a sidestream of the milk protein production, might be upgraded to a dairy product of higher value by the enzymatic in situ production of epilactose.

Key words: cellobiose 2-epimerase, epilactose, prebiotic, lactose, milk

\section{INTRODUCTION}

Lactose (4-O- $\beta$-D-galactopyranosyl-D-glucopyranose) is a disaccharide that occurs naturally in milk. During the heat treatment of milk, some lactose derivatives, namely lactulose (4-O- $\beta$-D-galactopyranosyl-D-fructose) and epilactose (4-O- $\beta$-D-galactopyranosyl-D-mannose; Olano and Calvo, 1989; Olano et al., 1989, 1992), are generated through the Lobry de Bruyn-Alberda van Ekenstein transformation (Moreno, 2003; SchusterWolff-Bühring et al., 2010). Recent literature suggests that epilactose has prebiotic properties (Nishimukai et al., 2008; Watanabe et al., 2008; Suzuki et al., 2010a,b); therefore, it is appropriate to produce epilactose directly in dairy products for potential future application in the food industry.

Cellobiose 2-epimerases (CE; EC 5.1.3.11) catalyze the formation of epilactose (Ito et al., 2007; Ojima et al., 2013); CE activity was first described by Tyler and Leatherwood (1967). Epimerization activity toward cellobiose was detected in the culture broth of the ruminal bacterium Ruminococcus albus 7 ATCC 27210 and CE was later identified as a biocatalyst catalyzing the reaction. Currently, $14 \mathrm{CE}$ have been described. These enzymes catalyze the epimerization of the $\mathrm{C} 2$ hydroxyl group of the reducing end of 1,4-linked oligosaccharides (Ojima et al., 2013). Three CE have been found to 
catalyze not only the epimerization (e.g., lactose to epilactose), but also the isomerization to lactulose (Park et al., 2011, 2013; Kim et al., 2012). The CE described have a molecular weight of about $45 \mathrm{kDa}$ and the temperatures of optimal activity are in a broad range from 30 to $80^{\circ} \mathrm{C}$. All $\mathrm{CE}$ show very low $\mathrm{AA}$ sequence homologies, but all feature common structural elements. They share structural similarities with $\mathrm{N}$-acyl-D-glucosamine 2-epimerases (AGE; Ito, 2009), including the $(\alpha / \alpha)_{6}$ fold. Therefore, the AA sequences of AGE have been used as a search template for the identification of new CE from databases.

The crystal structure of the CE from $R$. albus (RaCE; Fujiwara et al., 2013a) and Rhodothermus marinus ( $\boldsymbol{R} \boldsymbol{m} \mathbf{C E}$; Fujiwara et al., 2014) were released recently. The crystal structures confirmed the structure proposed previously by Ito et al. (2007). The basic conformation of $\mathrm{CE}$ consists of $12 \alpha$-helices arranged in an $(\alpha / \alpha)_{6}$ barrel structure. The active site, with its triple histidine center (Fujiwara et al., 2013a), is located inside the barrel.

In the current study, we identified 2 novel CE, 1 each from the obligate anaerobic, mesophilic bacterium Cellulosilyticum lentocellum and from the facultative anaerobic, mesophilic bacterium Dysgonomonas gadei. The focus of our study was the characterization of the undescribed CE with regard to potential industrial application in milk products. Therefore, biochemical characterizations of the 2 enzymes were carried out in buffer matrix and in milk and milk ultrafiltrate (MUF). An industrial application potential of the novel $\mathrm{CE}$ was demonstrated. Lactose in the food matrix MUF has been enzymatically converted to epilactose in both a batch and a continuous process.

\section{MATERIALS AND METHODS}

\section{Chemicals, Enzymes, Milk, and MUF}

All chemicals were of analytical grade or higher and supplied from Sigma-Aldrich (St. Louis, MO), Carl Roth (Karlsruhe, Germany), or Merck (Darmstadt, Germany). The T4 DNA ligase was purchased from Fisher Scientific (Schwerte, Germany) and restriction enzymes and DNA polymerase were purchased from New England Biolabs (Ipswich, MA). Milk for biochemical characterizations was obtained from a local supermarket (Weidemilch, Ultrahocherhitzt, 1.5\% Fett, Schwarzwaldmilch GmbH, Freiburg, Germany).

Biotransformations were carried out in UHT MUF (obtained from the University of Hohenheim-owned Dairy for Training and Research). This ultrafiltrate was produced from UHT milk by membrane fractionation via a $10 \mathrm{kDa}$ molecular cut-off membrane
(GR73PP-6338/48; Alfa Laval, Lund, Sweden). The lactose content was $48.3 \pm 1.3 \mathrm{~g} / \mathrm{L}$ and the protein content was $581 \mathrm{mg} / \mathrm{L}$ (using the Bradford method).

\section{Microorganisms, Plasmids, and Cloning}

The AA sequences representing putative $\mathrm{CE}$ from $C$. lentocellum and D. gadei were identified in UniProtKB/ TrEMBL (association no. F2JR71 and F5ITJ6; The UniProt Consortium, 2014). The DNA preparations from C. lentocellum DSM 5427 and D. gadei DSM 22811 were obtained from DSMZ (Leibniz Institut DSMZDeutsche Sammlung von Mikroorganismen und Zellkulturen, Braunschweig, Germany) for later expression of the wild-type genes heterologously in Escherichia coli. The specific primer pair clce_fw (5' CGCGGGATCCGTGTTTGTTGCAGAAGTAAAAG $3^{\prime}$ ) and clce_rev (5' GCGCGGATCCTAACTCGAGAACATTAATATCCCTCCTGATG $3^{\prime}$ ) were used for PCR amplification of the coding sequence for F2JR71. The resulting PCR fragment was called $C L C E$. The coding sequence for F5ITJ6 (named DGCE) was amplified by PCR with the primer pair dgce_fw (5' CGGCGGATCCATGAACGGATTCAGGAAAGAATTAATCG-

GAAAC $\left.3^{\prime}\right)$ and dgce_rev (5' CGCGGATCCTTACTCGAGATCAATTCCAAAATGTTCTAACATTTC $3^{\prime}$ ).

The BamHI and XhoI restriction sites (underlined) for cloning were added to the wild-type sequences via both primer pairs. A hexahistidine-tag $\left(\mathbf{H i s}_{6}\right.$-tag) was added by cloning into pET-20b $(+)$ vectors. The resulting plasmids, pET-20bCLCEHIS and pET-20bDGCEHIS, were introduced into E. coli XL-1 Blue (New England Biolabs, Ipswich, MA). The plasmids were transformed in E. coli JM109(DE3) and E. coli Rosetta-gami(DE3) for protein production.

\section{Culture Conditions}

The CE were produced in baffled shaking flasks for analytical purposes. Thus, 1-L shaking flasks were inoculated with $4 \mathrm{~mL}$ of an overnight preculture of E. coli JM109 pET-20bCLCEHIS or E. coli JM109 pET-20bDGCEHIS. The main culture was propagated in $200 \mathrm{~mL}$ of Terrific broth medium $(24 \mathrm{~g} / \mathrm{L}$ of yeast extract, $12 \mathrm{~g} / \mathrm{L}$ of tryptone, $4 \mathrm{~mL} / \mathrm{L}$ of glycerol, $17 \mathrm{mM}$ $\mathrm{KH}_{2} \mathrm{PO}_{4}, 72 \mathrm{mM} \mathrm{K} \mathrm{HPO}_{4}$, pH 7.0, $100 \mu \mathrm{g} / \mathrm{mL}$ of ampicillin; Carl Roth, Karlsruhe, Germany). The cultures were cultivated at $37^{\circ} \mathrm{C}$ until the transcription of the $\mathrm{CE}$ was induced at an optical density of $600 \mathrm{~nm}$ of 0.6 with $0.5 \mathrm{~m} M$ isopropyl $\beta$-D-1-thiogalactopyranoside. Thereafter, the cultivation was continued at $20^{\circ} \mathrm{C}$ for an additional $24 \mathrm{~h}$.

Additionally, E. coli Rosetta-gami pET-20bDGCE$H I S$ was cultivated in $12 \mathrm{~L}$ of Terrific broth medium 
supplemented with $100 \mu \mathrm{g} / \mathrm{mL}$ of ampicillin and $25 \mu \mathrm{g} / \mathrm{mL}$ of chloramphenicol in a 23-L stirred-tank reactor (Biostat E, B. Braun, Melsungen, Germany) at $37^{\circ} \mathrm{C}$. The $\mathrm{pH}$ was maintained at 7.0 by $0.6 \mathrm{M} \mathrm{H}_{3} \mathrm{PO}_{4}$. Expression was induced by adding $0.5 \mathrm{mM}$ isopropyl $\beta$-D-1-thiogalactopyranoside at an optical density of $600 \mathrm{~nm}$ of 3.2. After an overall cultivation time of $9 \mathrm{~h}$, cells were harvested by centrifugation $\left(8,000 \times g, 4^{\circ} \mathrm{C}\right.$, $15 \mathrm{~min})$.

\section{Protein Quantification}

The determination of the concentration of protein was carried out via the Bradford method (Bradford, 1976). Bovine serum albumin was used as a standard; SDS-PAGE was used for the evaluation of protein expression and purity after purification. The gels consisted of a $12 \%$ (wt/vol) acrylamide separation gel and a $6 \%$ (wt/vol) acrylamide stacking gel. The visualization of protein bands was carried out using Coomassie Brilliant Blue staining, according to the Fairbanks method (Wong et al., 2000). Broad Range Protein Marker $(2-212 \mathrm{kDa})$ from New England Biolabs was used as a protein standard.

\section{Purification of CE}

Harvested cells were resuspended in $20 \mathrm{mM}$ Tris$\mathrm{HCl}$ buffer $\mathrm{pH} 8$ containing $150 \mathrm{mM} \mathrm{NaCl}$ and $20 \mathrm{mM}$ imidazole resulting in a $30 \%$ (wt/vol) cell suspension. This suspension was subjected to a sonication on ice for 10 cycles each of $1 \mathrm{~min}$ of sonication (95\% amplitude, 0.5 cycles) and a 1-min pause (UP200S/S3; Hielscher Ultrasonics, Teltow, Germany) for cell lysis. Cell debris was removed by centrifugation $\left(8,000 \times g, 4^{\circ} \mathrm{C}, 15 \mathrm{~min}\right)$ and subsequent filtration $(0.45 \mu \mathrm{m})$.

Batch purifications were carried out for analytical preparations of CE from Cellulosilyticum lentocellum and Dysgonomonas gadei ( $\mathbf{C l C E}$ and $\mathbf{D g} \mathbf{C E}$, respectively). The crude extract was injected into an ÄKTA System (GE Healthcare, Little Chalfont, UK). The purification was carried out using affinity chromatography (IMAC) with a 12-mL Ni-IDA column (Ni-Profinity IMAC, Bio-Rad, Hercules, CA) equilibrated with loading buffer $(20 \mathrm{~m} M$ Tris- $\mathrm{HCl}$ containing $150 \mathrm{mM} \mathrm{NaCl}$ and $20 \mathrm{mM}$ imidazole, $\mathrm{pH} \mathrm{8.0)}$. The protein of interest was eluted using a linear gradient of imidazole $(20-500 \mathrm{mM})$ for 4 column volumes with a flow rate of $1 \mathrm{~mL} / \mathrm{min}$ at room temperature. Active fractions were pooled and the buffer was changed by size-exclusion chromatography (SEC; PD-10 column, GE Healthcare) to $20 \mathrm{mM}$ Tris-HCl buffer, $\mathrm{pH} 8.0$ for $C l C E$ and $\mathrm{pH} 7.5$ for $D g \mathrm{CE}$ for the determinations of the temperature profiles in buffer and the kinetic parameters. The buffer was exchanged to $2 \mathrm{~m} M$ 3-morpholinopropane1-sulfonic acid/NaOH (MOPS) buffer, $\mathrm{pH} 7.5$ or 8.0, for the $\mathrm{pH}$ profile and the temperature profile in milk and MUF. These buffer exchanges were carried out via SEC (PD-10 column, GE Healthcare).

The $D g \mathrm{CE}$ was purified by an automated enzyme purification system (Bioline chromatography system, Knauer Wissenschaftliche Geräte GmbH, Berlin, Germany) for the biotransformations. The instrumental setup was the same as described previously (Eisele et al., 2012; Stressler et al., 2012, 2013) apart from the columns used. For the purification of $D g \mathrm{CE}$, about $150 \mathrm{~mL}$ of $E$. coli crude extract obtained by sonication was loaded via a superloop (150 mL; GE Healthcare) onto a $12-\mathrm{mL} \mathrm{Ni}^{2+}$ charged Profinity IDA column (NiProfinity IMAC, Bio-Rad) equilibrated with loading buffer $(20 \mathrm{~m} M$ Tris- $\mathrm{HCl}$ containing $150 \mathrm{mM} \mathrm{NaCl}$ and $20 \mathrm{~m} M$ imidazole, $\mathrm{pH} 7.5$ ). The whole purification procedure was carried out at a flow rate of $2 \mathrm{~mL} / \mathrm{min}$ at room temperature. Elution from the first column was achieved by a buffer shift to $20 \mathrm{~m} M$ Tris- $\mathrm{HCl}$ containing $150 \mathrm{mM} \mathrm{NaCl}$ and $200 \mathrm{~m} M$ imidazole, $\mathrm{pH}$ 7.5. The eluting protein fraction was parked in a second superloop $(50 \mathrm{~mL}$; GE Healthcare) and loaded onto a desalting column afterward (HiPrep 26/10 Desaling $53 \mathrm{~mL}$; GE Healthcare). This SEC step was carried out to exchange the buffer containing imidazole with a $2 \mathrm{mM}$ MOPS buffer $\mathrm{pH}$ 7.5. The final fraction $(20 \mathrm{~mL})$ was freeze-dried (Alpha 1-2; Martin Christ Gefriertrocknungsanlagen, Osterode am Harz, Germany) to obtain a lyophilized $D g \mathrm{CE}$ preparation for biotransformation applications and later use.

\section{Enzyme Assays}

Thin layer chromatography was carried out for the qualitative activity evaluation of the CE. Thus, about $50 \mu \mathrm{L}$ of glucose, fructose, lactose, lactulose, cellobiose, or maltose at concentrations of $300 \mathrm{mM}$ in $20 \mathrm{mM}$ Tris-HCl buffer were mixed with $50 \mu \mathrm{L}$ of purified $\mathrm{CE}$ solution. After $16 \mathrm{~h}$ of incubation at $40^{\circ} \mathrm{C}$, the samples were diluted 1:5 with water and $1 \mu \mathrm{L}$ was loaded onto a thin layer chromatography plate (Silica 60 F245; Merck). Visualization of the reaction products was carried out with diphenylamine aniline, as described by Stahl (1967). $N$-Acetylglucosamine was also tested qualitatively for conversion. The assay was the same as for the other sugars, but $1 \mathrm{nmol}$ of ATP was added to the reaction tube. Investigation of the reaction products was carried out by HPLC.

The standard assay for the determination of enzyme activity was carried out as follows. An amount of $100 \mu \mathrm{L}$ of substrate solution $(50 \mathrm{~g} / \mathrm{L}$ of lactose in $20 \mathrm{~m} M$ Tris- $\mathrm{HCl}, \mathrm{pH} 8.0$ for $C l \mathrm{CE}$ or $\mathrm{pH} 7.5$ for $D g \mathrm{CE}$ ) 
was added to $100 \mu \mathrm{L}$ of sample containing $\mathrm{CE}$. The reaction at $40^{\circ} \mathrm{C}$ was stopped after $10 \mathrm{~min}$ for $\mathrm{ClCE}$ and after 2 min for $D g \mathrm{CE}$ with $400 \mu \mathrm{L}$ of $1 \mathrm{M} \mathrm{HClO}_{4}$.

Samples of $1 \mathrm{~mL}$ were taken and a SEC (PD-10 column, GE Healthcare) for matrix exchange and sugar separation was carried out for the evaluation of the enzyme activity during biotransformations. The assay was performed as stated previously with an adapted incubation time, with the resulting $\mathrm{CE}$ fraction in $20 \mathrm{mM}$ Tris-HCl, $\mathrm{pH} 8.0$ for $C l \mathrm{CE}$ or $\mathrm{pH} 7.5$ for $\mathrm{DgCE}$. These assays were followed by HPLC analysis to determine the concentration of the reaction products.

\section{HPLC Method}

An HPLC system (Spectra System, Thermo Fisher Scientific, Waltham, MA) was used for the determination of reaction products from conversions catalyzed by $\mathrm{CE}$. Therefore, a sample preparation adapted from Erich et al. (2012) was carried out as follows. After stopping the reaction, $200 \mu \mathrm{L}$ of $2 M \mathrm{KOH}$ was added to the reaction mixture to reach a neutralized solution. Subsequently, $200 \mu \mathrm{L}$ of a $50 \mathrm{mM}$ inositol solution (serving as an internal standard) was added, and double-distilled water was also added to achieve a final volume of $2 \mathrm{~mL}$. After incubation on ice for $15 \mathrm{~min}$, the sample was centrifuged $\left(20,000 \times g, 4^{\circ} \mathrm{C}, 3 \mathrm{~min}\right)$ and $50 \mu \mathrm{L}$ of the sample was injected into the HPLC system. The HPLC was equipped with a Eurokat $\mathrm{Pb}^{2+}$ column (Vertex Plus $300 \times 8 \mathrm{~mm} 10 \mu \mathrm{m}$; Knauer Wissenschaftliche Geräte $\mathrm{GmbH}$ ) at $85^{\circ} \mathrm{C}$ and a refractive index detector (Spectra System RI-150, Thermo Fisher Scientific) at $50^{\circ} \mathrm{C}$. The mobile phase was double-distilled water with a flow rate of $0.60 \mathrm{~mL} / \mathrm{min}$. Retention times were $13.1 \mathrm{~min}$ for lactose, $16.1 \mathrm{~min}$ for epilactose, and $27.0 \mathrm{~min}$ for inositol.

\section{Determination of Biochemical Parameters}

The native size of the CE was evaluated by SEC. Therefore, $30 \mu \mathrm{L}$ of the purified enzyme solution was loaded onto a 24-mL Sephadex 200 10/300 GL column (GE Healthcare). The flow rate was $0.5 \mathrm{~mL} / \mathrm{min}$ and the mobile phase was $50 \mathrm{~m} M$ sodium phosphate buffer at $\mathrm{pH} 7.0$ supplemented with $150 \mathrm{mM} \mathrm{NaCl}$. The sizes were calculated according to a calibration curve (Gel filtration calibration Kit LMW; GE Healthcare) based on the retention time obtained. Furthermore, the activity of the peak fraction was tested by the standard assay with overnight incubation.

Purified CE in $2 \mathrm{~m} M$ MOPS buffer was used for the determination of the $\mathrm{pH}$ profile. A $50 \mathrm{-g} / \mathrm{L}$ lactose solution in $20 \mathrm{~m} M$ modified Britton-Robinson buffer $(20 \mathrm{~m} M$ acetic acid, $20 \mathrm{~m} M$ phosphoric acid, and
$20 \mathrm{~m} M$ glycine) was used as a substrate (Britton and Robinson, 1931). The $\mathrm{pH}$ value of the substrate solution varied between $\mathrm{pH} 4$ and 11 by the addition of $\mathrm{NaOH}$. Conversions were carried out with $100 \mu \mathrm{L}$ of enzyme solution and $100 \mu \mathrm{L}$ of buffered substrate solution. After an appropriate time, the reaction was stopped by the addition of $400 \mu \mathrm{L}$ of $1 \mathrm{M} \mathrm{HClO}_{4}$. Sugar contents were determined by HPLC analysis.

A $20 \mathrm{~m} M$ Tris- $\mathrm{HCl}$ buffer was used at $\mathrm{pH} 8.0$ for $C l \mathrm{CE}$ and $\mathrm{pH} 7.5$ for $D g \mathrm{CE}$, respectively, to determine the temperature profile in buffer. An amount of $100 \mu \mathrm{L}$ of enzyme solution and $100 \mu \mathrm{L}$ of $50 \mathrm{~g} / \mathrm{L}$ of lactose in $20 \mathrm{mM}$ Tris- $\mathrm{HCl}$ at the accordant $\mathrm{pH}$ was added. Assay temperature varied between 8 and $90^{\circ} \mathrm{C}$. After an appropriate time, the reaction was stopped by the addition of $400 \mu \mathrm{L}$ of $1 \mathrm{M} \mathrm{HClO}_{4}$ and the reaction mixtures were analyzed by HPLC.

The determination of the temperature profile in $50 \%$ (vol/vol) milk and 100\% MUF was carried out using a purified enzyme preparation in $2 \mathrm{mM}$ MOPS and $100 \mu \mathrm{L}$ of substrate. The temperature varied between 8 and $90^{\circ} \mathrm{C}$. The determination of the temperaturedependent enzyme activity was carried out using the standard enzyme assay with an adapted conversion time and HPLC analysis.

Purified enzyme in $20 \mathrm{~m} M$ Tris- $\mathrm{HCl}$ buffer was used for the determination of the kinetic parameters. Lactose in $20 \mathrm{mM}$ Tris-HCl buffer at $\mathrm{pH} 8.0$ for $C l \mathrm{CE}$ and $\mathrm{pH}$ 7.5 for $D g \mathrm{CE}$ served as the substrate, and the lactose concentration varied between 20 and $437.5 \mathrm{~m} M$. The assay was carried out by adding $175 \mu \mathrm{L}$ of substrate solution to $25 \mu \mathrm{L}$ of enzyme solution. The reaction was stopped after $10 \mathrm{~min}$ for $\mathrm{ClCE}$ and $5 \mathrm{~min} D g \mathrm{CE}$ by adding $400 \mu \mathrm{L}$ of $1 \mathrm{M} \mathrm{HClO}_{4}$. Analysis of the sugars was performed by HPLC.

\section{Biotransformations}

Batch biotransformations were carried out in $50-\mathrm{mL}$ stirred vessels with a $20 \mathrm{~mL}$ working volume at $8 \pm$ $2^{\circ} \mathrm{C}$ for $28 \mathrm{~h}$. First, $433.2 \pm 18.8$ nkat of purified $D g \mathrm{CE}$ in $2 \mathrm{~m} M$ MOPS (equivalent to $21.7 \mathrm{nkat} / \mathrm{mL}$ of MUF) was freeze-dried directly in the reaction vessel. Then the bioconversion was started by the addition of MUF to the experimental setup. All experiments were carried out in duplicate in 2 separate vessels. A third vessel without enzyme served as a negative control. Samples, each of $1.5 \mathrm{~mL}$, were taken for the quantification of sugars and measurement of residual enzyme activity. The sugar content was determined by HPLC. To determine the residual $\mathrm{CE}$ activity, $1 \mathrm{~mL}$ of the sample was subjected to SEC (PD-10 column, GE Healthcare) to exchange the matrix and to remove sugars. Subsequently, the standard assay was carried out. The mi- 


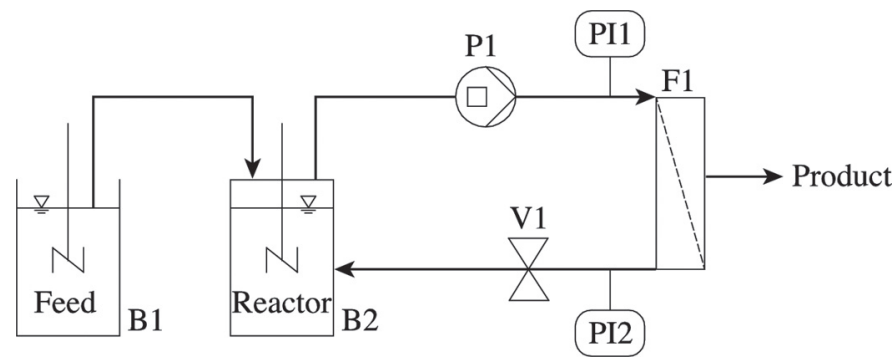

Figure 1. Schematic flow diagram of the enzyme membrane reactor $(\mathrm{EMR})$ setting. $\mathrm{P} 1=$ hose pump; PI1, PI2 = pressure gauge; F1 $=$ tangential flow membrane module; $\mathrm{B} 1=$ feed tank $(2.0 \mathrm{~L}) ; \mathrm{B} 2=$ stirred reaction vessel $(0.5 \mathrm{~L}) ; \mathrm{V} 1=$ transmembrane pressure regulation valve.

crobial stability of the systems was checked by plating aliquots of $100 \mu \mathrm{L}$ on plate count agar plates $(2.5 \mathrm{~g} / \mathrm{L}$ of yeast extract, $5 \mathrm{~g} / \mathrm{L}$ of peptone, $1 \mathrm{~g} / \mathrm{L}$ of glucose, and $15 \mathrm{~g} / \mathrm{L}$ of agar). The number of colony-forming units was counted after $48 \mathrm{~h}$ of incubation at $30^{\circ} \mathrm{C}$.

A continuous biotransformation was carried out in an enzyme membrane reactor (EMR). The setup consisted of a $500-\mathrm{mL}$ stirred vessel, a $10-\mathrm{kDa}$ molecular weight cut-off (MWCO) polyethersulfone tangential flow membrane (Minimate TFF Capsule; Pall Corporation, Port Washington, NY), and a feed tank (Figure $1)$. The whole setup was operated at $8 \pm 2^{\circ} \mathrm{C}$; MUF from the same batch as in the batch biotransformation served as substrate and feed solution. During the operation time of $6 \mathrm{~d}, 2.8 \mathrm{~L}$ of MUF was processed. About $5.20 \pm 0.23 \mu$ kat $D g \mathrm{CE}$ in $2 \mathrm{~m} M$ MOPS (equivalent to $21.7 \mathrm{nkat} / \mathrm{mL}$ of MUF), obtained from the automated purification, was freeze-dried in the reaction vessel (as described previously) and the EMR was started by the addition of $240 \mathrm{~mL}$ of MUF. Transmembrane pressure was continuously monitored by a pressure gauge and initially set to $50 \mathrm{kPa}$. The resulting eluate flux was aimed to be $20 \mathrm{~mL} / \mathrm{h}$. This flux was kept constant by adjusting the transmembrane pressure. This resulted in a residence time of $12 \mathrm{~h}$. Eluate samples were taken on a regular basis by collecting the efflux for 3 min. From these samples, the flux (by weighing) and sugar content (by HPLC) were determined. Moreover, samples from the reaction vessel were taken to monitor microbial stability and the CE activity. For the microbial stability, $100 \mu \mathrm{L}$ of sample was spread on plate count agar plates and microbial counts were evaluated. The enzyme activity was measured after SEC (PD-10 column, GE Healthcare) by the standard assay (see above). The eluate was collected in separate batches (12 h each). Sugar content (by HPLC) and enzyme activity was also measured in these batches to check for possible enzyme leakage (by standard assay after SEC with $24 \mathrm{~h}$ of incubation time).

\section{Statistics and Replication of Experiments}

All enzymatic assays and analytic measurements were performed at least in duplicate. Statistical analyses, calculation, and visualization were carried out using SigmaPlot 12 (Systat Software, San Jose, CA) or Excel 2007 (Microsoft Corporation, Redmond, WA). The kinetic parameters were calculated by nonlinear regression fitting with the Enzyme Kinetics Module of SigmaPlot 12 (Systat Software).

\section{RESULTS}

\section{Selection of Putative CE and Confirmation of Epimerization Activity}

We carried out a sequence similarity search with the Basic Local Alignment Search Tool (The UniProt Consortium, 2014) for the in silico identification of novel CE. Whole AA sequences of the known CE from $R$. albus (UniProtKB E6UB41; Ito et al., 2007), as well as the whole AA sequence of Caldicellulosiruptor saccharolyticus CE (UniProtKB A4XGA6; Kim and Oh, 2012) were used as search templates. The search was refined by checking the results for the known $(\alpha / \alpha)_{6}$ barrel structure of AGE (Lee et al., 2007; Ito, 2010) by PSIPRED (Buchan et al., 2013) and the presence of reported residues responsible for the $\mathrm{CE}$ activity (Ito et al., 2009). Among others, the CE-like proteins UniProtKB F2JR71 and UniProtKB F5ITJ6 were identified with identities of 54 and $40 \%$ compared with $R a \mathrm{CE}$ (Figure 2). The sequence identity between both F2JR71 and F5ITJ6 was also low, at 40\%. The catalytic residues of $\mathrm{RaCE}$ (His184, His243, and His374) have been identified in both sequences (Mu et al., 2013) and been predicted to be His190, His249, and His380 in F2JR71, and His184, His243, and His373 in F5ITJ6. The 395-AA-long sequence F2JR71 was automatically translated from the gene locus European Nucleotide Archive, association number ADZ85052.1, of Cellulosilyticum lentocellum DSM 5427. This microorganism was isolated by Murray et al. (1986) from river sediment with paper mill waste. Cellulosilyticum lentocellum is an anaerobic bacterium belonging to the class Clostridia and the phylum of Firmicutes. The second extracted AA sequence (F5ITJ6) is 388 AA long. The coding nucleotide sequence is EGJ99380.1, which was obtained from Dysgonomonas gadei DSM 22811. Dysgonomonas gadei is a facultative anaerobically growing bacterium belonging to the class and phylum of Bacteroidetes and was isolated from a human gall bladder (Hofstad et al., 2000).

After cloning the wild-type genes (Supplementary Figures S1 and S2; http://dx.doi.org/10.3168/jds.2015- 
E6UB41|RACE MMISEIRQELTDHIIPEWN-KLRDDENGGFYGYLSYGLELDKKADKGVILHSR ILWEYSN 59 F2 JR 71 |C1CE MFVAEVKEHLVNGIIP EWK-KLR DNTYGGYYGYMNYDLELDOTÄIKGCILNSR IMWEFSN 59 F5 ITJ6 | DgCE --MNGFRKELIGNILP EWINKMODNHNGGFYGOIDGNNMLNSRANKGAILNAR ILWTESS 58

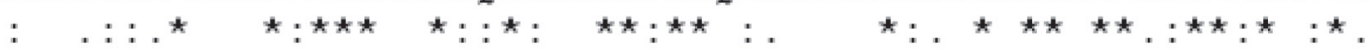

E6UB41|RACE AYMTLGGDELLDNAKHAYEEIKNNCIDYEYGGVYWMMDEEGKPADTMKHTYNIÄFAYAL 119 F2JR71/CICE AYLTLKDESLLEEATHAFEFMKAHCIDYKYGGVYWMLDYKGNP VEDMKHTYNOAFAIYAL 119 F5 ITJ6 |DgCE AYR ILKNEEYLKMAORAFDYIVAYF IDKEYGGAFWELDYKGNPVNTKKOTYVQGEMLYGF 118

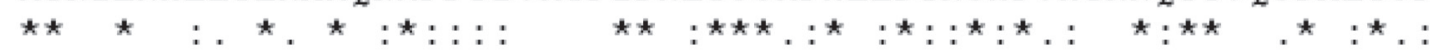

E6UB41|RACE SSYYRASGDKEALALAYRLEEDIEKNT-LDEYGYREAFDRQWRLVDNEALSE------NG 172 E2JR71|C1CE \$SYYVASGNSEALDLAMGLFHKIESTC-KDEYGYLEAFDRTWEP IDNHKLSDNKHMESEG 178 F5 ITJ6|DgCE SEYFRATGEOKALELAKDFFYLIEKYRDKVTGGYPEAFTRDWQP IEDMRLSDK------D 172

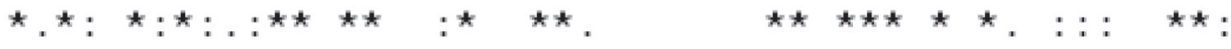

E6UB41|RACE LKADKTMNAILHLIEAYTELYKADGNEKVADRLKEQLGOMRDIVYTP DTNALKVEFDTAF 232 F $2 J R 71$ |C1CE KVAEKTMNTILHVLEAYTELYRVGKDVEVGRCLEKLLOMTELKVYNKEKROLEVEFDTOL 238 F5 ITJ6 | DgCE ENEVKTMNTHLH ILEPYTNLCR IWKDEQLES AORQL IDVFTDK ILDSNTNHLNLFFDEDW 232 $\star \star \star \star: \star \star:: \star \star \star: \star \quad: \quad: \quad:: \quad$ : $:$ : $\boldsymbol{\nabla} \boldsymbol{\nabla}$

E6UB41|RACE NLVGDIH SYGHDIEATWLMDR ACDVLGDEDLKKOF AEMDLK ISHNIODIALEDGALNNER 292 E 2 JR 71 |CICE RSIADMH SYGHDIEAAWLLDR AALVLGNODIIDRTKAYTVR IAYKVKEVAFEKGALNNER 298 F5 ITJ6|DgCE NVKSTAV SYGHDIEASWLLEEAAEVLGDKALIAEIKDLSLKIADAASGGIGVDGSMIYEY 292 $\star \star \star \star \star \star \star \star: \star \star: . \star . \star \star \star::$ : . $: \star$ : . $\star$ : :

E6UB41|RACE DKNEIDKTRVWWVQAEAVVGF INAYOHSGDEKFLESAKSVWENIKEYIIDKREGGEWYSE 352 F 2 JR 71 |CICE FNNDIDKTR IWWVQAESVVGF IN AYEKTODVAFLEVAKEIWQYIKTYF IDSRAHSEWYWO 358 F5 ITJ6 |DGCE KNGHMDTERHWWVQAEAVVGYMYAYRNSKNAIYKERASQVWSYIQSRMVDN-ENGEWYWS 351

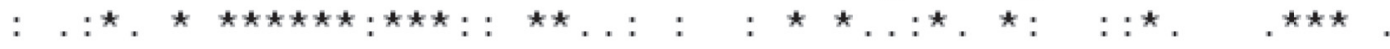

E6UB41|RACE VTEDHTPHDYKETVGPWKCPYHNGRMCMEVITR-GVDI 389 E2 JR 71 ICICE VDENGRP NKS YP IVEPWKCP YHNGRMCLEV IRR-DINV 395 F5 ITJ6 |DgCE RLPDGSINRKDDKAGEWKCPYHNGRMCMEMLEHEGID- 388

Figure 2. Alignment of Ruminococcus albus cellobiose 2-epimerase (RaCE; E6UB41), Cellulosilyticum lentocellum cellobiose 2-epimerase (ClCE; F2JR71), and Dysgonomonas gadei cellobiose 2-epimerase (DgCE; F5ITJ6). Similar AA are marked with periods (.) and colons (:); identical amino acids are highlighted by an asterisk $\left(^{*}\right)$. Catalytic active residues in RaCE are marked by $\mathbf{\nabla}$. Alignment was constructed with UniProt/Clustal (The UniProt Consortium, 2014).

9411) into the expression vectors, the genes were expressed by E. coli. Fractions containing protein that bound to the Ni-IDA column were used for confirmation of CE activity. Both proteins, F2JR71 and F5ITJ6, showed enzymatic activity against cellobiose and lactose. The monosaccharides glucose, fructose, and $N$ acetylglucosamine, as well as the disaccharide maltose, did not serve as substrates for either enzymes (Table 1). Therefore, F2JR71 was identified as a novel CE, which we named $\mathrm{ClCE}$; the second novel $\mathrm{CE}$ (F5ITJ6) identified was named $D g \mathrm{CE}$. Quantitative HPLC analyses of the conversion products of lactose showed that lactose was epimerized to epilactose for both CE. No formation of lactulose was detected, even in elongated 
Table 1. Substrate spectrum of novel cellobiose 2-epimerases (CE) from Cellulosilyticum lentocellum and Dysgonomonas gadei ${ }^{1}$

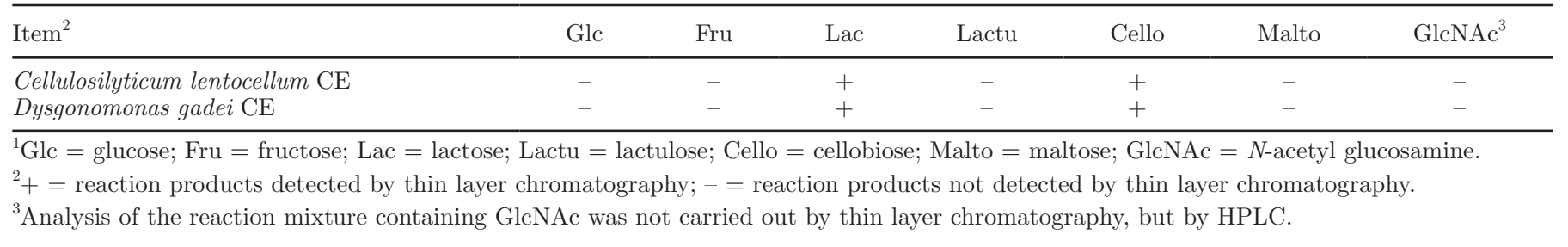

incubation for $24 \mathrm{~h}$, by either enzyme. Moreover, the cellobiose was converted to a single reaction product, which was assumed to be glucosylmannose (Ojima et al., 2011). The measured activity was higher in both CE toward cellobiose ( $C l \mathrm{CE}$ : $24.3 \mathrm{nkat} / \mathrm{mL}$; $D g \mathrm{CE}$ : 118.0 nkat $/ \mathrm{mL}$ ) than toward lactose (ClCE: 12.6 nkat/ $\mathrm{mL} ; D g \mathrm{CE}: 108.0 \mathrm{nkat} / \mathrm{mL}$ ). Also, the molecular size of the purified enzymes was determined (Table 2). The theoretically calculated size for $C l C E$ was $46 \mathrm{kDa}$. Similar sizes were observed under denaturing conditions by SDS-PAGE (Figure 3) and SEC under native conditions with sizes of 43 and $52 \mathrm{kDa}$, respectively. A theoretical size of $45 \mathrm{kDa}$ was calculated for $D g \mathrm{CE}$, which was confirmed by SDS-PAGE with a size of $42 \mathrm{kDa}$ (Figure 3). A size of $33 \mathrm{kDa}$ was evaluated via SEC under native conditions.

\section{Effects of $\mathrm{pH}$ and Temperature on Enzyme Activity}

We investigated the $\mathrm{pH}$ and the temperature profiles of both CE (Table 2). The $\mathrm{pH}$ profile was tested in universal Britton-Robinson buffer (Britton and Robinson, 1931), whereas the temperature profile was tested in buffer system, as well as in milk and MUF.

The highest activity was exhibited by $C l \mathrm{CE}$ at $\mathrm{pH}$ $8.0(100 \%=83.0 \mathrm{nkat} / \mathrm{mL})$. Besides the $\mathrm{pH}$ optimum, the activity dropped quickly. No activity was measured below $\mathrm{pH} 4.0$ or above 11.0. At $\mathrm{pH} 7.0$, we detected about $85 \%$ residual activity. Concerning the optimal assay temperature, the enzyme showed maximal activity at $40^{\circ} \mathrm{C}$ in Tris- $\mathrm{HCl}$ buffer $\mathrm{pH} 8.0$, in $50 \%$ milk and in MUF (applied enzyme activities: $40.1 \mathrm{nkat} / \mathrm{mL}$ in buffer, $35.4 \mathrm{nkat} / \mathrm{mL}$ in milk, and $18.4 \mathrm{nkat} / \mathrm{mL}$ in MUF). The temperature optimum is the same in defined buffer solution at an optimal $\mathrm{pH}$, in milk and in MUF. In comparison to the temperature optimum, an activity of $16 \%$ in buffer and milk and $20 \%$ in MUF was measured at $8^{\circ} \mathrm{C}$. No activity was measured at temperatures higher than $80^{\circ} \mathrm{C}$ in milk and MUF matrix and $90^{\circ} \mathrm{C}$ in buffer matrix. The optima of $D g \mathrm{CE}$ differed moderately by means of the $\mathrm{pH}$ optimum and the temperature optima. The $\mathrm{pH}$ profile of $\mathrm{DgCE}$ showed an optimum at $\mathrm{pH} 7.5(100 \%=192.3 \mathrm{nkat} / \mathrm{mL})$. No activity was measured below pH 4.0 or above 11.0, which is identical for
$D g \mathrm{CE}$ and $\mathrm{ClCE}$, and we observed about $97 \%$ activity at a $\mathrm{pH}$ of 7.0 .

Differences in the temperature profiles of $D g \mathrm{CE}$ in buffer and $50 \%$ milk, as well as in MUF matrix were observed. The optimal activity could be detected at $40^{\circ} \mathrm{C}$ in buffer matrix $(100 \%=467.5 \mathrm{nkat} / \mathrm{mL})$, whereas it was $50^{\circ} \mathrm{C}$ in milk and MUF matrix $(100 \%=112.0$ nkat $/$ $\mathrm{mL}$ for milk and 277.3 for MUF). Above the optima at $60^{\circ} \mathrm{C}$, the activity dropped fast to $3 \%$ in buffer, and $17 \%$ in milk and MUF. At an assay temperature of $8^{\circ} \mathrm{C}$ activities of 2,9 , and $7 \%$ were measured in buffer, milk, and MUF, respectively.

\section{Kinetic Parameters of Lactose Epimerization}

For comparison of the kinetic performance of $\mathrm{ClCE}$ and $D g C E$ in lactose epimerization, the kinetic parameters were investigated. For the epimerization reaction, a Michaelis-Menten-like kinetic was observed for both CE. The $C l C E$ showed an apparent $K_{m}$ (Michaelis

Table 2. Biochemical characterization of novel cellobiose 2-epimerases (CE) from Cellulosilyticum lentocellum and Dysgonomonas gadei

\begin{tabular}{|c|c|c|}
\hline Item & $\begin{array}{l}\text { Cellulosilyticum } \\
\text { lentocellum } \mathrm{CE}\end{array}$ & $\begin{array}{l}\text { Dysgonomonas } \\
\text { gadei } \mathrm{CE}\end{array}$ \\
\hline \multicolumn{3}{|l|}{ Molecular mass (kDa) } \\
\hline Calculated $^{1}$ & 46 & 45 \\
\hline SDS-PAGE & 43 & 42 \\
\hline Size exclusion chromatography & 52 & 33 \\
\hline $\mathrm{pH}_{\text {optimum }}^{2}$ & 8.0 & 7.5 \\
\hline \multicolumn{3}{|l|}{ Temperature optimum ${ }^{3}\left({ }^{\circ} \mathrm{C}\right)$} \\
\hline Buffer & 40 & 40 \\
\hline Milk & 40 & 50 \\
\hline MUF & 40 & 50 \\
\hline$K_{m}^{4}(\mathrm{~m} M)$ & 129 & 108 \\
\hline $\mathrm{v}_{\max } 4($ nkat $/ \mathrm{mL})$ & 92 & 173 \\
\hline
\end{tabular}

${ }^{1}$ Sizes were calculated by ExPASy (http://www.expasy.org/).

${ }^{2}$ The $\mathrm{pH}$ profiles were evaluated in $20 \mathrm{~m} M$ modified Britton-Robinson buffer of the $\mathrm{pH}$ range from 4 to 11 .

${ }^{3}$ Temperature profiles were measured in Tris- $\mathrm{HCl}$ buffer at the $\mathrm{pH}$ optimum, in $50 \%$ (vol/vol) milk or milk-ultrafiltrate (MUF), respectively.

${ }^{4}$ Kinetic parameters $\left(K_{m}=\right.$ Michaelis constant; $\mathrm{v}_{\max }=$ maximum enzyme rate) were determined at the $\mathrm{pH}$ and temperature optimum with lactose concentrations from 20 to $437.5 \mathrm{~m} M$. Parameters were calculated by nonlinear regression fitting with the Enzyme Kinetics Module of SigmaPlot 12 (Systat Software Inc., San Jose, CA). 


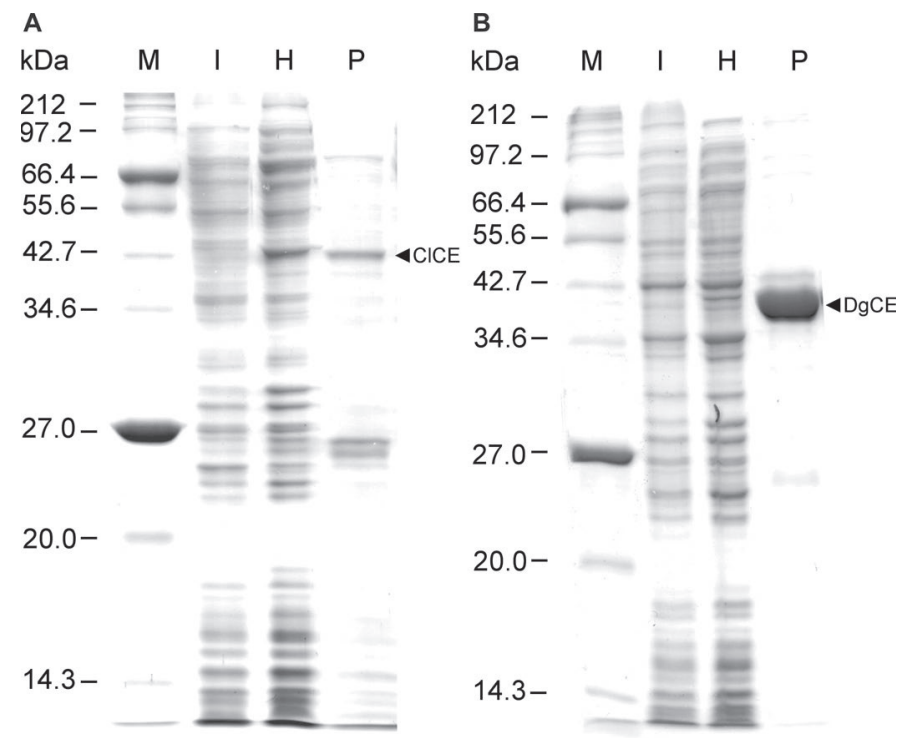

Figure 3. Sodium dodecyl sulfate-PAGE of novel cellobiose 2-epimerases (CE) fractions: Cellulosilyticum lentocellum $\mathrm{CE}(\mathrm{A})$ and Dysgonomonas gadei $\mathrm{CE}$ (B). Lane $\mathrm{M}=$ molecular mass marker; lane I $=$ crude protein solution at time of induction; lane $\mathrm{H}=\mathrm{CP}$ solution at time of harvest; lane $\mathrm{P}=\mathrm{CE}$-active fraction after purification (affinity chromatography and desalting by size exclusion chromatography).

constant) value of $129 \pm 14 \mathrm{~m} M$ and $\mathrm{v}_{\max }$ (maximum enzyme rate) of $92 \pm 4 \mathrm{nkat} / \mathrm{mL}$ toward lactose. The $D g \mathrm{CE}$ showed a slightly higher affinity for lactose and a higher maximal conversion speed: the $K_{m}$ value was 108 $\pm 5 \mathrm{~m} M$ and the $\mathrm{v}_{\max }$ was $173 \pm 3 \mathrm{nkat} / \mathrm{mL}$ (Table 2).

\section{Production and Purification of DgCE for Biotransformations}

With the aim of preparing 1 standardized batch of a $D g \mathrm{CE}$ formulation, the enzyme was produced in a 12-L stirred-tank reactor. Escherichia coli Rosettagami contained the plasmid pET-20bDGCEHIS, which was the expression host. During the $9 \mathrm{~h}$ of cultivation (Figure 4), bacterial growth was observed for $5.5 \mathrm{~h}$ after inoculation. Thereafter, the cell mass was constant at $9.5 \mathrm{~g} / \mathrm{L}$ (bio DM) until the cells were harvested at the end of cultivation. The CE formation was growthrelated, reaching a total activity of $49.0 \mu \mathrm{kat}$ at the end of cultivation.

For purification of $D g \mathrm{CE}$ from $114 \mathrm{~g}$ (bio DM) of $E$. coli cells, an automated 2-step purification was carried out. After cell disruption, $150 \mathrm{~mL}$ of cell-free extract was handled automatically and, after a total runtime of $290 \mathrm{~min}$, a $20-\mathrm{mL}$ fraction containing $D g \mathrm{CE}$ was obtained in a single run (Figure 5). In total, $20.3 \mu$ kat (specific activity: $572.6 \mathrm{nkat} / \mathrm{mg}$ ) of $D g \mathrm{CE}$ were obtained after 7 single runs in buffer for lyophilization (content of the whole bioreactor). This $D g \mathrm{CE}$ activity is according to a yield of $41 \%$.

\section{Production of Epilactose in MUF by DgCE}

For biotransformations, a lyophilized, standardized $D g C E$ preparation from the automated purification was used (CE activity: $572.6 \mathrm{nkat} / \mathrm{mg}$ ). The epilactose formation was investigated with $D g \mathrm{CE}$ as a biocatalyst and MUF as matrix and substrate in batch biotransformations and in a continuously operated EMR. A process temperature of $8^{\circ} \mathrm{C}$, a temperature suitable for milk processing in the dairy industry, was chosen.

The mean values of the batch biotransformations are shown in Figure 6. The biotransformation with 21.7 nkat $/ \mathrm{mL}$ of $D g C E$ resulted in $14.44 \pm 0.53 \mathrm{~g} / \mathrm{L}$ of epilactose. Therefore, the epilactose yield compared with the initial lactose content of MUF was $29.9 \%$. The apparent reaction equilibrium was established after $10 \mathrm{~h}$ and remained constant until the biotransformation was stopped after $28 \mathrm{~h}$. After this time, $D g \mathrm{CE}$ showed $90 \%$ of the initial activity. For verification of the assumed reaction equilibrium, fresh $D g \mathrm{CE}$ was added to the reaction mixture again. This did not change the sugar concentrations, indicating the true equilibrium. Calculating the enzyme productivity (expressed as the amount of epilactose formed per $D g \mathrm{CE}$ activity applied) at the time of the establishment of equilibrium $(10 \mathrm{~h})$, a value of $0.68 \mathrm{mg} / \mathrm{nkat}$ was obtained. The whole system

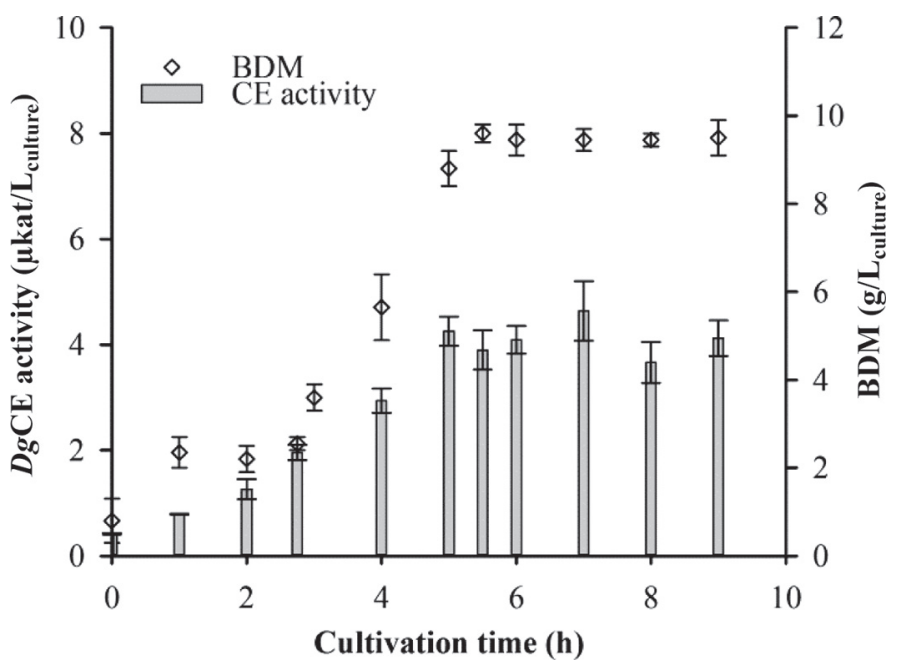

Figure 4. Bioreactor cultivation of Escherichia coli Rosetta-gami pET-20bDGCEHIS on a 12-L scale [medium: Terrific broth (Carl Roth, Karlsruhe, Germany), $37^{\circ} \mathrm{C}, \mathrm{pH}$ 7.0]. Enzyme activity was measured after cell disruption and purification. The culture was induced with $0.5 \mathrm{~m} M$ isopropyl $\beta$-D-1-thiogalactopyranoside at $2 \mathrm{~h}$ after inoculation. $\mathrm{BDM}=$ bio dry matter; $\mathrm{Dg} \mathrm{CE}=$ Dysgonomonas gadei cellobiose 2-epimerase. Error bars represent SD. 


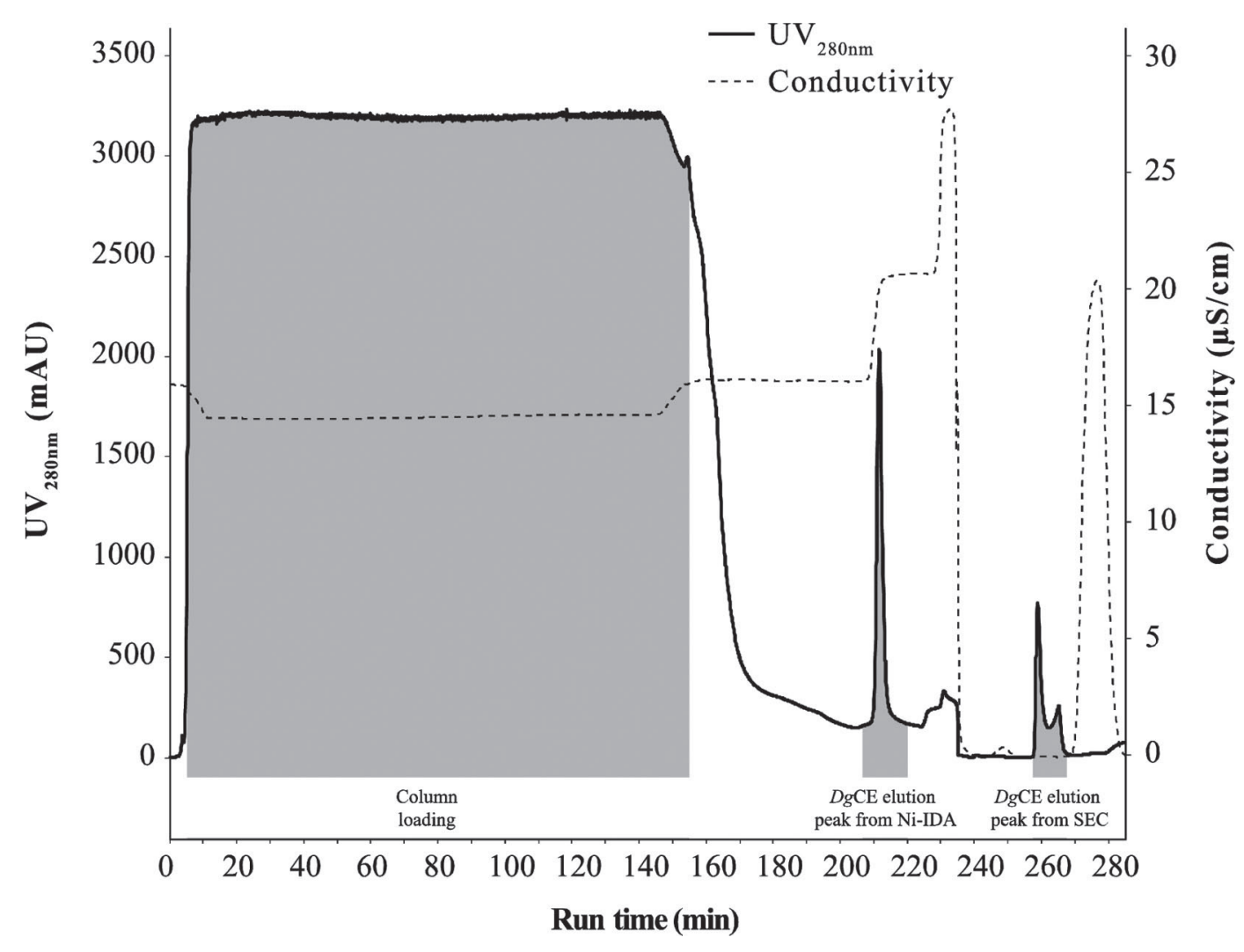

Figure 5. Automated 2-step purification of Dysgonomonas gadei cellobiose 2-epimerase ( $\mathrm{DgCE})$. About $150 \mathrm{~mL}$ of cell-free extract was loaded into a Ni-IDA column ( 1 column volume $=12 \mathrm{~mL}$; Ni-Profinity IMAC, Bio-Rad, Hercules, CA). The first peak corresponds to the cellobiose 2-epimerase-containing elution peak from the Ni-IDA. In a subsequent step, the buffer of this fraction was exchanged with $2 \mathrm{~m} M$ 3-morpholinopropane-1-sulfonic acid at pH 7.5 by size exclusion chromatography (SEC) utilizing a Hi Prep 26/10 desalting column (1CV = 15 mL; HiPrep 26/10 Desaling 53 mL, GE Healthcare, Little Chafont, UK).

was microbiologically stable (cell counts after $28 \mathrm{~h}=$ $\left.2 \cdot 10^{2} \mathrm{cfu} / \mathrm{mL}\right)$.

We carried out a continuous biotransformation under identical conditions as in the batch transformation by using EMR technology. A 10,000-Da MWCO membrane retained the $D g \mathrm{CE}$ within the reaction vessel. Enzyme leakage of $D g \mathrm{CE}$, which is 3 times larger than the pore size, was not observed by checking $\mathrm{CE}$ activity in the permeate. Moreover, the system could be operated under stable flux for $6 \mathrm{~d}$, leading to the assumption that no or very little membrane fouling, caused by the low residual protein content $(581 \mathrm{mg} / \mathrm{L})$ of MUF, was occurring. The $D g \mathrm{CE}$ showed an operational stability for the $6 \mathrm{~d}$ of operation with a residual activity of $31 \%$ at the end. After $2 \mathrm{~d}$ of operation, a plate count of $3.6 \times$ $10^{5} \mathrm{cfu} / \mathrm{mL}$ was determined. To prevent further growth, $\mathrm{NaN}_{3}$ was added at this point.

The enzyme activity was the same in both processes, batch and EMR, with 21.6 nkat $/ \mathrm{mL}$. We chose a residence time of $12 \mathrm{~h}$ for the EMR process because the time to reach equilibrium in the batch process was approximately $10 \mathrm{~h}$. According to the reactor volume of $240 \mathrm{~mL}$, a theoretical permeate flux of $20 \mathrm{~mL} / \mathrm{h}$ was targeted. The actual average flux was $19.8 \pm$ $1.2 \mathrm{~mL} / \mathrm{h}$. This resulted in a total permeate volume of $2.8 \mathrm{~L}$ within the operation time of $144 \mathrm{~h}$ [equal to 11.6 volume replacements (VR)]. Stable epilactose concentration in the permeate at a mean concentration of $8.93 \pm 0.67 \mathrm{~g} / \mathrm{L}$ was measured $8 \mathrm{~h}(0.7 \mathrm{VR})$ after starting the EMR. This corresponded to a yield of $18.5 \%$ epilactose. In total, the EMR process produced about $24 \mathrm{~g}$ of epilactose. During the operation time, the epilactose concentration decreased slightly from $9.93 \pm 0.43$ (after $14 \mathrm{~h} ; 1.1 \mathrm{VR}$ ) to $7.27 \pm 0.16$ $\mathrm{g} / \mathrm{L}$ (after $132 \mathrm{~h} ; 10.9 \mathrm{VR}$ ). The respective spacetime yield decreased from the maximum of 0.80 to $0.57 \mathrm{~g} / \mathrm{L}$ per hour. An average enzyme productivity of $4.56 \mathrm{mg} / \mathrm{nkat}$ was achieved after $12 \mathrm{VR}$ (Figure 7). In the batch process, an enzyme productivity of only $0.68 \mathrm{mg} / \mathrm{nkat}$ was achieved because the biocatalyst has to be replaced with every new batch (1 VR). This means that about $571 \%$ more epilactose could be produced in the EMR process with the same $D g C E$ activity as used in the batch process. 
KREWINKEL ET AL.

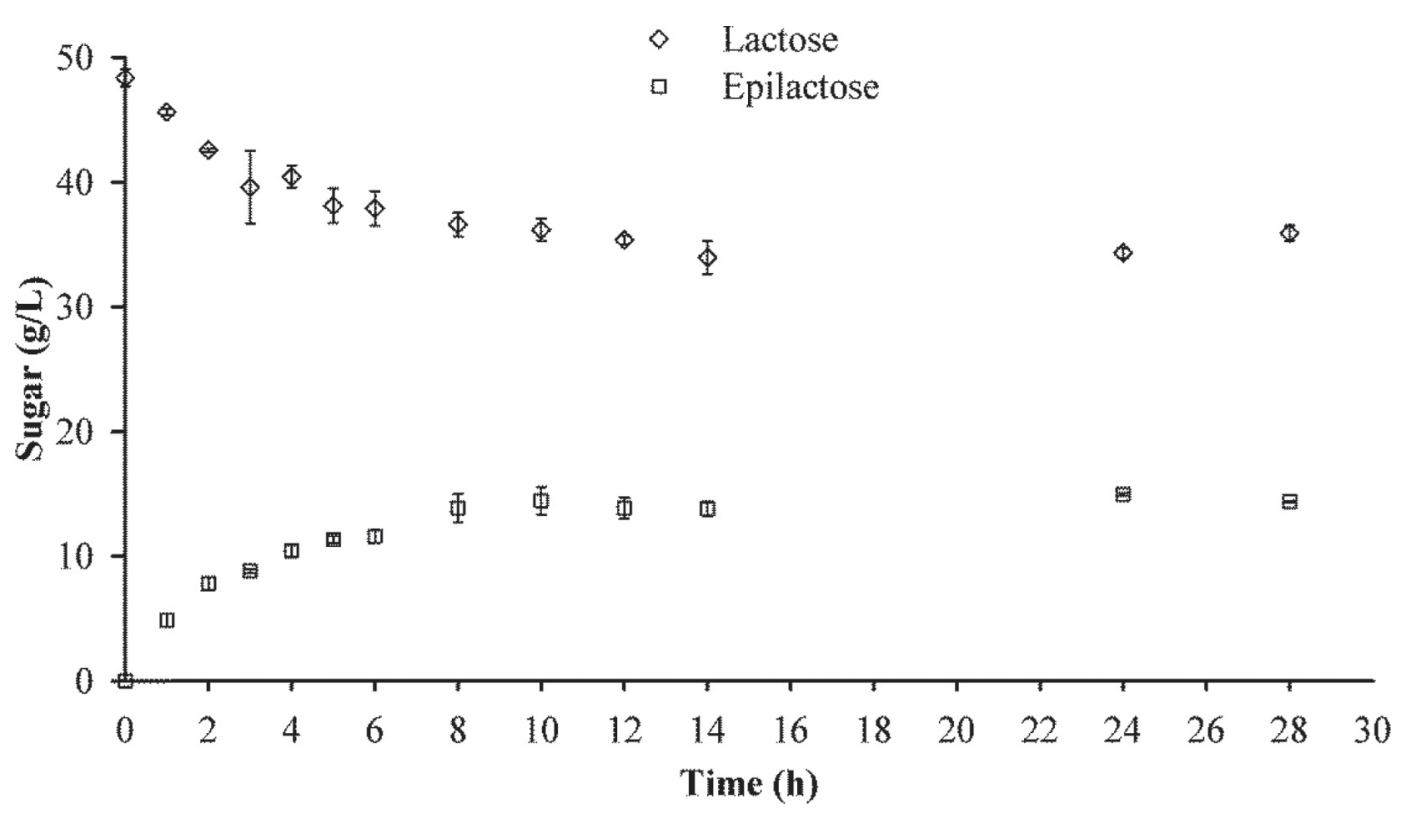

Figure 6. Time course of epilactose production in milk ultrafiltrate by Dysgonomonas gadei cellobiose 2-epimerase (CE) in batch mode (mean values of 2 independent biotransformations). The working volume was $20 \mathrm{~mL}$. Error bars represent SD.

\section{DISCUSSION}

\section{Assignment of the Gene Products Obtained to the Enzyme Class of CE}

We provide evidence that 2 DNA sequences from $C$. lentocellum and D. gadei are coding for CE activity. We proved that the recombinant enzymes catalyze a C2epimerization reaction of the glucose or mannose motive of $\beta$-1,4-linked disaccharides. An activity against monosaccharides was not detected. This substrate spectrum is similar to the CE, which form epilactose as previously described (Ito et al., 2008; Taguchi et al., 2008; Senoura et al., 2009; Ojima et al., 2011, 2013). Lactulose also does not serving as a substrate for $\mathrm{ClCE}$ and $D g \mathrm{CE}$. This distinguishes the novel CE identified from the lactulose-forming CE, Caldicellulosiruptor saccharolyticus CE (Park et al., 2011), Dictyoglomus turgidum CE (Kim et al., 2012), and Spirochaeta thermophila CE (Park et al., 2013). The $\alpha$-1,4-linked disaccharide maltose is not accepted as a substrate for $\mathrm{ClCE}$ or $D g \mathrm{CE}$, which was also reported for $R a \mathrm{CE}$ (Ito et al., 2007) and RmCE (Ojima et al., 2011).

The $C l \mathrm{CE}$ and $D g \mathrm{CE}$ both originate from mesophilic, anaerobic bacteria, similar to most known $\mathrm{CE}$ that produce epilactose. Cellulosilyticum lentocellum is taxonomically grouped to the Clostridia, whereas $D$. gadei is grouped to the phylogenetically very distant Bacteroides. Involvement of $\mathrm{ClCE}$ in a cellulose pathway is imaginable because $C$. lentocellum is a bacterium which degrades cellulose slowly. Cellulose degradation was not reported for D. gadei. However, an involvement of both enzymes in a mannan-degrading pathway, as assumed by Senoura et al. (2009) for other CE, might be possible. This mannan-degrading pathway has been suggested for Bacteroides fragilis CE (BfCE; Senoura et al., 2011), $R a \mathrm{CE}$ (Kawahara et al., 2012) and $R m \mathrm{CE}$ (Kawahara et al., 2012). The physiological function of $C l \mathrm{CE}$ and $D g \mathrm{CE}$ is not clear and has to be proven by further sequence analyses and experimental data.

Similar to the taxonomical distance between the bacteria from which $C l \mathrm{CE}$ and $D g \mathrm{CE}$ are derived, the sequences of the $\mathrm{CE}$ share low overall sequence homologies of only $40 \%$. The low sequence homology observed between the $2 \mathrm{CE}$ is also noticeable between all CE reported (Mu et al., 2013). However, the secondary structure prediction suggests that the protein structure of the novel $\mathrm{CE}$ is similar to the enzymes reported. Moreover, AA residues reported responsible for disaccharide binding and catalysis are present in the structures (Figure 2). Three histidine residues, which have been reported to be essential for catalysis in $R a \mathrm{CE}$ (Fujiwara et al., 2013a) and $R m \mathrm{CE}$ (Fujiwara et al., 2014), have been identified in the primary sequences of $C l \mathrm{CE}$ and $D g \mathrm{CE}$. These findings on the AA sequence level indicate that the newly identified enzymes follow the same catalytic mechanism as that suggested for $R a \mathrm{CE}$ (Amein and Leatherwood, 1969; Ito et al., 2009; Fujiwara et al., 2013a) and confirmed for $R m \mathrm{CE}$ (Fujiwara et al., 2014). 


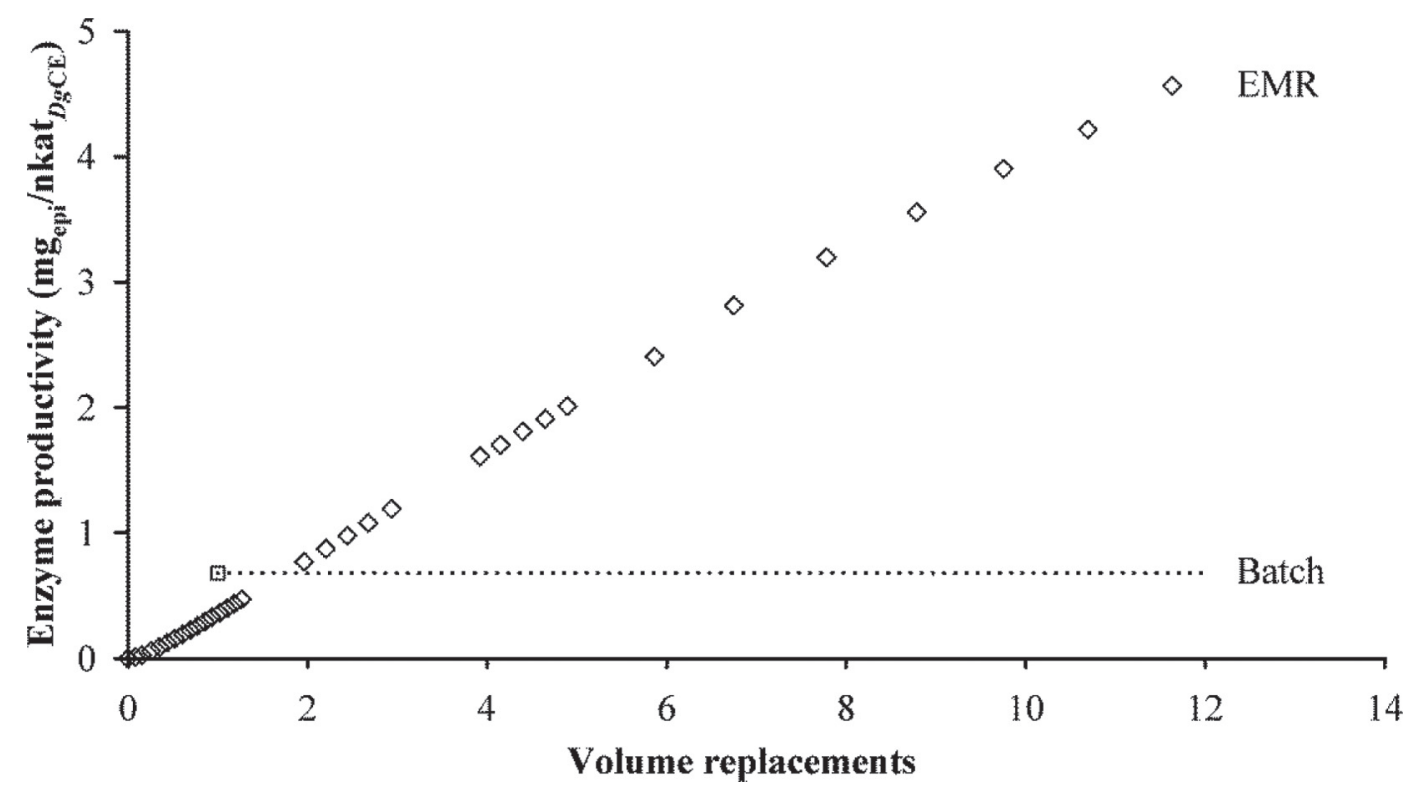

Figure 7. Dependency of the Dysgonomonas gadei cellobiose 2-epimerase ( $D g \mathrm{CE}$ ) efficiency on the number of volume replacements in the batch process and in enzyme membrane reactor (EMR) process.

\section{Biochemical Properties of CICE and DgCE}

The biochemical characterizations of the enzymes identified are in accordance with literature about $\mathrm{CE}$ reported previously. As is often observed for enzymes from mesophilic organisms, both enzymes exhibit the temperature optimum at a mesophilic temperature of $40^{\circ} \mathrm{C}$ in buffer. For CE that form epilactose, temperature optima in different buffer systems ranging from 35 to $50^{\circ} \mathrm{C}$ have been reported. Currently, only 1 enzyme that forms epilactose, $R m \mathrm{CE}$, with a higher temperature optimum of $80^{\circ} \mathrm{C}$ has been reported (Ojima et al., 2011). For $D g \mathrm{CE}$, a stabilizing effect shifting the temperature optimum to $50^{\circ} \mathrm{C}$ in milk and $\mathrm{MUF}$ was observed. This is probably caused by the ionic composition of these matrices. We did not observe this effect for $C l C E$. About $7 \%$ activity of the maximal $D g C E$ activity was preserved at a process temperature for the biotransformations of $8^{\circ} \mathrm{C}$. This activity was suitable to carry out batch and continuous biotransformations of MUF. Similar residual activities of 5.5\% (Flavobacterium johnsoniae $\mathrm{CE} ; \boldsymbol{F j C E}$ ) and $15.9 \%$ (Pedobacter heparinus $\mathrm{CE} ; \boldsymbol{P h C E}$ ) were shown to be suitable in biotransformations of milk published previously (Krewinkel et al., 2014). The $\mathrm{pH}$ profiles of $\mathrm{ClCE}$ and $\mathrm{DgCE}$ determined showed the highest activities at slightly alkaline $\mathrm{pH}$ values. This is also true for all $\mathrm{CE}$ reported. The optimum of $C l C E$ is $\mathrm{pH} 8.0$ and of $D g \mathrm{CE}$ is $\mathrm{pH} 7.5$. Activities at neutral $\mathrm{pH}$ values found in milk and MUF are appropriate with $85(C l C E)$ and $97 \%(D g \mathrm{CE})$ for biotransformations in these matrices. The $\mathrm{pH}$ profiles are consistent with the assumption that histidine residues with a $\mathrm{p} K_{a}$ (acid dissociation constant) of 6.0 are involved in the catalytic mechanism.

The molecular sizes of $C l \mathrm{CE}$ and $D g \mathrm{CE}$ actually determined under denaturing conditions on SDS-PAGE are in accordance with the theoretically calculated molecular mass. With a molecular mass of about 43 $(C l \mathrm{CE})$ and $42 \mathrm{kDa}(D g \mathrm{CE})$, the sizes of the enzymes are similar to the sizes for CE reported previously, ranging from 41 to $47 \mathrm{kDa}$. Under native conditions, the size for $\mathrm{ClCE}$ was slightly larger $(52 \mathrm{kDa})$, indicating that the enzyme is active in a monomeric state. We also confirmed a monomeric state for $D g \mathrm{CE}$. However, the size measured by SEC under native conditions was $33 \mathrm{kDa}$. Activity was confirmed in the elution fractions of SEC, verifying the identity of the enzyme and the active monomeric state. Based on the size of $33 \mathrm{kDa}$ for $D g \mathrm{CE}$, a membrane with an MWCO of $10 \mathrm{kDa}$ was selected for the EMR setup and later proven to be suitable by measuring no enzyme leakage.

The kinetic parameters for both CE were determined under similar conditions as those described in literature (Taguchi et al., 2008; Ojima et al., 2011, 2013). Nevertheless, comparing the values was difficult. Reported $K_{m}$ values for lactose among recombinant $\mathrm{CE}$ are diverse, ranging from $6.6 \mathrm{~m} M$ (BfCE; Senoura et al., 2009) to $238 \mathrm{mM}$ (Teredinibacter turnerae CE; Ojima et al., 2013). The novel CE identified exhibit high $K_{m}$ values for lactose. The $K_{m}$ of $C l C E$ is $129 \mathrm{mM}$ and for 
$D g \mathrm{CE}$ is $108 \mathrm{~m} M$. These values support the assumption that lactose might not be the prior substrate. Nevertheless, the affinity of $D g \mathrm{CE}$ to lactose was suitable to carry out the biotransformations of lactose in MUF. However, utilization of $\mathrm{CE}$ with a higher affinity to lactose, such as the mesophilic BfCE (Senoura et al., 2009), might lead to even more effective processes in diluted lactose solution. Alternatively, utilization of lactose concentrates with higher lactose concentrations compared with the $K_{m}$ values of CE would be advantageous for achieving more efficient processes.

\section{Production of DgCE}

For the biotransformations, $D g \mathrm{CE}$ was produced in a 12-L stirred-tank reactor indicating the possibility of a later upscaling to larger fermentation processes. This resulted in a total $D g \mathrm{CE}$ activity of $49.0 \mu \mathrm{kat}$. After automated purification, $20.3 \mu$ kat of $D g \mathrm{CE}$ were obtained, which accounts for a yield of $41 \%$ and a specific activity of $572.6 \mathrm{nkat} / \mathrm{mg}$. The purification yield and specific activity are comparable to yields for $P h \mathrm{CE}$ reported previously (Krewinkel et al., 2014). The utilized expression system, E. coli Rosetta-gami, in combination with the pET system providing the $\mathrm{His}_{6}$-tag, was suitable for $\mathrm{CE}$ production. The $\mathrm{His}_{6}$-tag allowed a reproducible and fast automated purification of $D g \mathrm{CE}$ with short hands-on time $(D g \mathrm{CE}$ activity in the final fractions from 7 consecutive runs varied between 125.3 and $153.0 \mathrm{nkat} / \mathrm{mL}$ ). With respect to a later application of these enzymes in food technology, an expression in antibiotic-free food-grade expression systems seems indispensable.

\section{Biotransformation of Lactose-Containing Foodstuff}

The biotransformations with $D g \mathrm{CE}$ as biocatalyst were carried out at $8^{\circ} \mathrm{C}$, which is a suitable storage and process temperature for milk. The substrate and matrix of both biotransformations was MUF, a highly available sidestream product of milk protein production. The lactose content of MUF is comparable with the content of milk, but only marginal protein is present. The lactose content of about $48.3 \mathrm{~g} / \mathrm{L}$ makes this foodstuff attractive as a valuable source for epilactose production. Due to the low protein content, a long operation time of more than $6 \mathrm{~d}$ with stable fluxes were achieved. Membrane fouling, which is caused by macromolecule deposition at the EMR membrane, was not observed. The lactose of MUF could be converted to a product of higher value with both processes, batch and continuous, because the in situ production of the putative prebiotic disaccharide epilactose (Lange and Vogel, 2009) was shown.
Within $10 \mathrm{~h}$ of operation of the batch process, $14.4 \mathrm{~g} / \mathrm{L}$ of epilactose was produced from the initial lactose content $(48.3 \mathrm{~g} / \mathrm{L})$ of MUF. This led to a mean conversion yield of $29.9 \%$. This equilibrium was confirmed by further operation of the process up to $28 \mathrm{~h}$ and the addition of fresh enzyme.

A similar biotransformation in milk was reported in earlier works by Krewinkel et al. (2014) and led to comparable results. In our study, the mesophilic CE $P h \mathrm{CE}$ and $F j \mathrm{CE}$ were used under identical reaction conditions $\left(8^{\circ} \mathrm{C}, 20-\mathrm{mL}\right.$ reaction volume) for a biotransformation of milk lactose. With enzyme activities of 352 and 199 nkat, about 30.5 and $33.6 \%$ conversion yield were achieved within $9 \mathrm{~h}$ of biotransformation for $P h \mathrm{CE}$ and FjCE, respectively. Saburi et al. (2010) showed a conversion yield of approximately $27 \%$ in a bioconversion carried out by $R a \mathrm{CE}$. This biotransformation was performed at room temperature in $15 \mathrm{~L}$ of sodium phosphate buffer containing $3 \mathrm{~kg}$ of lactose monohydrate for $48 \mathrm{~h}$ (Saburi et al., 2010). The $R m \mathrm{CE}$ reached a conversion yield of about $30 \%$ epilactose in a biochemical sodium phosphate buffer system in another bioconversion (Sato et al., 2012). This reaction was carried out with an immobilized $\mathrm{CE}$ at $50^{\circ} \mathrm{C}$ for $10 \mathrm{~d}$.

To enhance the enzyme productivity and lower the effort for enzyme production for epilactose production a continuous biotransformation with an EMR was carried out. It was remarkable that the EMR process ran with a stable product flux for $6 \mathrm{~d}$. In total, $24 \mathrm{~g}$ of epilactose were produced. This yield was achieved with the same $D g$ CE activity (21.7 nkat $/ \mathrm{mL}$ ) as in the batch process, where $288 \mathrm{mg}$ of epilactose were produced. Considering the enzyme productivity of both processes, the EMR, with $144 \mathrm{~h}$ of operation time (11.6 VR) was about 6 times more productive than the batch process. Considering that enzyme inactivation and leakage were negligibly low and $D g \mathrm{CE}$ was acceptably active when stopping the EMR after 6 d of operation, a longer EMR runtime, leading to even higher enzyme productivity, would have been possible. Microbiological stability was acceptable until $d$. Thereafter, addition of a bacteriostatic agent was necessary to keep this laboratory process stable. Bacterial growth was caused by a nonsterile handling of the feed solution and subsequent concentration of the MUF-inherent microorganisms during the EMR operation. These difficulties are to be avoided by sterile handling of the feed MUF or a direct implementation of the EMR module after the UHT process in a sterile fashion.

Nevertheless, with this proof of principle study, we showed for the first time that epilactose could be produced continuously from a sidestream food matrix. A direct application of the MUF that contains epilactose 
for food applications or a further purification of the epilactose is conceivable.

In general, the industrial application of enzymatic epilactose production seems interesting due to the higher value of epilactose compared with lactose. Watanabe et al. (2008) recently reported on a bifidogenic effect of epilactose similar to lactulose in animal models. Currently, there is no industrial production process for epilactose; but the enzymatic process reported demonstrates the feasibility of epilactose formation from a cheap food sidestream product without formation of detectable by-products.

\section{REFERENCES}

Amein, M., and J. M. Leatherwood. 1969. Mechanism of cellobiose epimerase. Biochem. Biophys. Res. Commun. 36:223-227.

Bradford, M. M. 1976. A rapid and sensitive method for the quantitation of microgram quantities of protein utilizing the principle of protein-dye binding. Anal. Biochem. 72:248-254.

Britton, H. T. S., and R. A. Robinson. 1931. (CXCVIII) Universal buffer solutions and the dissociation constant of veronal. J. Chem. Soc. 1456-1462. http://dx.doi.org/10.1039/JR9310001456.

Buchan, D. W. A., F. Minneci, T. C. O. Nugent, K. Bryson, and D. T. Jones. 2013. Scalable web services for the PSIPRED protein analysis workbench. Nucleic Acids Res. 41:W349-57.

Eisele, T., T. Stressler, B. Kranz, and L. Fischer. 2012. Automated multi-step purification protocol for angiotensin-I-converting-enzyme (ACE). J. Chromatogr. B Analyt. Technol. Biomed. Life Sci. 911:64-70.

Erich, S., T. Anzmann, and L. Fischer. 2012. Quantification of lactose using ion-pair RP-HPLC during enzymatic lactose hydrolysis of skim milk. Food Chem. 135:2393-2396.

Fujiwara, T., W. Saburi, S. Inoue, H. Mori, H. Matsui, I. Tanaka, and M. Yao. 2013a. Crystal structure of Ruminococcus albus cellobiose 2-epimerase: Structural insights into epimerization of unmodified sugar. FEBS Lett. 587:840-846.

Fujiwara, T., W. Saburi, H. Matsui, H. Mori, and M. Yao. 2014. Structural insights into the epimerization of beta-1,4-linked oligosaccharides catalyzed by cellobiose 2-epimerase, the sole enzyme epimerizing non-anomeric hydroxyl groups of unmodified sugars. J. Biol. Chem. 289:3405-3415.

Hofstad, T., I. Olsen, E. R. Eribe, E. Falsen, M. D. Collins, and P. A. Lawson. 2000. Dysgonomonas gen. nov. to accommodate Dysgonomonas gadei sp. nov., an organism isolated from a human gall bladder, and Dysgonomonas capnocytophagoides (formerly CDC group DF-3). Int. J. Syst. Evol. Microbiol. 50:2189-2195.

Ito, S. 2009. Features and applications of microbial sugar epimerases. Appl. Microbiol. Biotechnol. 84:1053-1060.

Ito, S. 2010. Catalysis, structures, and applications of carbohydrate epimerases. J. Appl. Glycosci. 57:1-16.

Ito, S., S. Hamada, H. Ito, H. Matsui, T. Ozawa, H. Taguchi, and S. Ito. 2009. Site-directed mutagenesis of possible catalytic residues of cellobiose 2-epimerase from Ruminococcus albus. Biotechnol. Lett. 31:1065-1071.

Ito, S., S. Hamada, K. Yamaguchi, S. Umene, H. Ito, H. Matsui, T. Ozawa, H. Taguchi, J. Watanabe, J. Wasaki, and S. Ito. 2007. Cloning and sequencing of the cellobiose 2-epimerase gene from an obligatory anaerobe, Ruminococcus albus. Biochem. Biophys. Res. Commun. 360:640-645.

Ito, S., H. Taguchi, S. Hamada, S. Kawauchi, H. Ito, T. Senoura, J. Watanabe, M. Nishimukai, S. Ito, and H. Matsui. 2008. Enzymatic properties of cellobiose 2-epimerase from Ruminococcus albus and the synthesis of rare oligosaccharides by the enzyme. Appl. Microbiol. Biotechnol. 79:433-441.
Kawahara, R., W. Saburi, R. Odaka, H. Taguchi, S. Ito, H. Mori, and H. Matsui. 2012. Metabolic mechanism of mannan in a ruminal bacterium, Ruminococcus albus, involving two mannoside phosphorylases and cellobiose 2-epimerase: Discovery of a new carbohydrate phosphorylase, beta-1,4-mannooligosaccharide phosphorylase. J. Biol. Chem. 287:42389-42399.

Kim, J. E., Y. Kim, L. Kang, and D. Oh. 2012. Characterization of a recombinant cellobiose 2-epimerase from Dictyoglomus turgidum that epimerizes and isomerizes b-1,4- and a-1,4-gluco-oligosaccharides. Biotechnol. Lett. 34:2061-2068.

Kim, Y. S., and D. Oh. 2012. Lactulose production from lactose as a single substrate by a thermostable cellobiose 2-epimerase from Caldicellulosiruptor saccharolyticus. Bioresour. Technol. 104:668672.

Krewinkel, M., M. Gosch, E. Rentschler, and L. Fischer. 2014. Epilactose production by 2 cellobiose 2-epimerases in natural milk. J. Dairy Sci. 97:155-161.

Lange, E., and F. Vogel. 2009. Milk Consumption and Health. Nova Biomedical Books, New York, NY.

Lee, Y. C., H. Wu, Y. Chang, W. Wang, and W. Hsu. 2007. The central cavity from the (alpha/alpha)6 barrel structure of Anabaena sp. CH1 N-acetyl-D-glucosamine 2-epimerase contains two key histidine residues for reversible conversion. J. Mol. Biol. 367:895-908.

Moreno, F. J. 2003. Effect of high pressure on isomerization and degradation of lactose in alkaline media. J. Agric. Food Chem. 51:1894-1896.

Mu, W., Q. Li, C. Fan, C. Zhou, and B. Jiang. 2013. Recent advances on physiological functions and biotechnological production of epilactose. Appl. Microbiol. Biotechnol. 97:1821-1827.

Murray, W. D., L. Hoffman, N. L. Campbell, and R. H. Madden. 1986. Clostridium lentocellum sp. nov., a cellulolytic species from river sediment containing paper-mill waste. Syst. Appl. Microbiol. $8: 181-184$.

Nishimukai, M., J. Watanabe, H. Taguchi, T. Senoura, S. Hamada, H. Matsui, T. Yamamoto, J. Wasaki, H. Hara, and S. Ito. 2008. Effects of epilactose on calcium absorption and serum lipid metabolism in rats. J. Agric. Food Chem. 56:10340-10345.

Ojima, T., W. Saburi, H. Sato, T. Yamamoto, H. Mori, and H. Matsui. 2011. Biochemical characterization of a thermophilic cellobiose 2-epimerase from a thermohalophilic bacterium, Rhodothermus marinus JCM9785. Biosci. Biotechnol. Biochem. 75:2162-2168.

Ojima, T., W. Saburi, T. Yamamoto, H. Mori, and H. Matsui. 2013. Identification and characterization of cellobiose 2-epimerases from various aerobes. Biosci. Biotechnol. Biochem. 77:189-193.

Olano, A., and M. M. Calvo. 1989. Kinetics of lactulose, galactose and epilactose formation during heat-treatment of milk. Food Chem. 34:239-248.

Olano, A., M. M. Calvo, and N. Corzo. 1989. Changes in the carbohydrate fraction of milk during heating processes. Food Chem. $31: 259-265$.

Olano, A., G. Santa-Maria, N. Corzo, M. M. Calvo, I. Martinez-Castro, and M. L. Jimeno. 1992. Determination of free carbohydrates and amadori compounds formed at the early stages of non-enzymic browning. Food Chem. 43:351-358.

Park, C. S., J. Kim, S. Lee, Y. Kim, L. Kang, and D. Oh. 2013. Characterization of a recombinant mannobiose 2-epimerase from Spirochaeta thermophila that is suggested to be a cellobiose 2-epimerase. Biotechnol. Lett. 35:1873-1880.

Park, C. S., J. E. Kim, J. G. Choi, and D. K. Oh. 2011. Characterization of a recombinant cellobiose 2-epimerase from Caldicellulosiruptor saccharolyticus and its application in the production of mannose from glucose. Appl. Microbiol. Biotechnol. 92:11871196.

Saburi, W., T. Yamamoto, H. Taguchi, S. Hamada, and H. Matsui. 2010. Practical preparation of epilactose produced with cellobiose 2-epimerase from Ruminococcus albus NE1. Biosci. Biotechnol. Biochem. 74:1736-1737.

Sato, H., W. Saburi, T. Ojima, H. Taguchi, H. Mori, and H. Matsui. 2012. Immobilization of a thermostable cellobiose 2-epimerase from Rhodothermus marinus JCM9785 and continuous production of epilactose. Biosci. Biotechnol. Biochem. 76:1584-1587. 
Schuster-Wolff-Bühring, R., L. Fischer, and J. Hinrichs. 2010. Production and physiological action of the disaccharide lactulose. Int. Dairy J. 20:731-741.

Senoura, T., S. Ito, H. Taguchi, M. Higa, S. Hamada, H. Matsui, T. Ozawa, S. Jin, J. Watanabe, J. Wasaki, and S. Ito. 2011. New microbial mannan catabolic pathway that involves a novel mannosylglucose phosphorylase. Biochem. Biophys. Res. Commun. 408:701-706.

Senoura, T., H. Taguchi, S. Ito, S. Hamada, H. Matsui, S. Fukiya, A. Yokota, J. Watanabe, J. Wasaki, and S. Ito. 2009. Identification of the cellobiose 2-epimerase gene in the genome of Bacteroides fragilis NCTC 9343. Biosci. Biotechnol. Biochem. 73:400-406.

Stahl, E. 1967. Dünnschicht-Chromatographie: Ein Laboratoriumshandbuch. 2nd ed. Springer, Berlin, Germany.

Stressler, T., T. Eisele, M. Schlayer, and L. Fischer. 2012. Production, active staining and gas chromatography assay analysis of recombinant aminopeptidase P from Lactococcus lactis ssp. lactis DSM 20481. AMB Express 2:39.

Stressler, T., T. Eisele, M. Schlayer, S. Lutz-Wahl, and L. Fischer. 2013. Characterization of the recombinant exopeptidases PepX and PepN from Lactobacillus helveticus ATCC 12046 important for food protein hydrolysis. PLoS ONE 8:e70055.

Suzuki, T., M. Nishimukai, A. Shinoki, H. Taguchi, S. Fukiya, A. Yokota, W. Saburi, T. Yamamoto, H. Hara, and H. Matsui. 2010a. Ingestion of epilactose, a non-digestible disaccharide, improves postgastrectomy osteopenia and anemia in rats through the promotion of intestinal calcium and iron absorption. J. Agric. Food Chem. 58:10787-10792.

Suzuki, T., M. Nishimukai, M. Takechi, H. Taguchi, S. Hamada, A Yokota, S. Ito, H. Hara, and H. Matsui. 2010b. The nondigestible disaccharide epilactose increases paracellular ca absorption via rho-associated kinase- and myosin light chain kinase-dependent mechanisms in rat small intestines. J. Agric. Food Chem. 58:1927-1932.

Taguchi, H., T. Senoura, S. Hamada, H. Matsui, Y. Kobayashi, J. Watanabe, J. Wasaki, and S. Ito. 2008. Cloning and sequencing of the gene for cellobiose 2-epimerase from a ruminal strain of Eubacterium cellulosolvens. FEMS Microbiol. Lett. 287:34-40.

The UniProt Consortium. 2014. Activities at the universal protein resource (UniProt). Nucleic Acids Res. 42:D191-D198.

Tyler, T. R., and J. M. Leatherwood. 1967. Epimerization of disaccharides by enzyme preparations from Ruminococcus albus. Arch. Biochem. Biophys. 119:363-367.

Watanabe, J., M. Nishimukai, H. Taguchi, T. Senoura, S. Hamada, H. Matsui, T. Yamamoto, J. Wasaki, H. Hara, and S. Ito. 2008 Prebiotic properties of epilactose. J. Dairy Sci. 91:4518-4526.

Wong, C., S. Sridhara, J. C. Bardwell, and U. Jakob. 2000. Heating greatly speeds coomassie blue staining and destaining. Biotechniques 28:426-428., 430, 432. 